

\section{Many Uses}

Transpired collectors are ideal for industrial and commercial buildings with large ventilation requirements. More than 40 systems have been installed,
THE TRANSPIRED

AIR COLLECTOR

IS MORE EFFI-

CIENT, LESS

EXPENSIVE, AND

BETTER FOR

INDOOR AIR

PREVIOUS SOLAR

AIR COLLECTORS.
QUALITY THAN including several at major manufacturing plants. Other common applications include vehicle maintenance facilities, hazardous waste storage buildings, gymnasiums, airplane hangars, schools, and warehouses requiring ventilation.

Favorable factors for a cost-effective transpired collector installation include:

- Appropriate south-, southeast-, or southwestfacing wall

- Long heating season

- High utility rates for heating

- Relatively large ventilation requirement.

Transpired collectors generally are applicable wherever outside air must be heated. Collectors can also preheat combustion air for central-heating plants or industrial furnaces. However, transpired air collector systems may be inappropriate for some multistory buildings due to fire code problems as well as for buildings with existing heat-recovery systems.

Transpired air collector systems are being used in both the federal and private sectors. The Fort Carson Army Post in Colorado was the first federal facility to install a "solar wall." The transpired collector heats a new high-bay aviation maintenance facility by prewarming air and supplying the heated air to the building's central heating system. High-profile, private-sector industrial users include Ford Motor Company, McDonnell Douglas, General Motors Corporation (GM), and Federal Express. At a GM battery plant in Canada, Conserval installed a transpired collector to correct the ventilation problems of a steam-operated fan coil system for space heating. And a Federal Express Distribution Facility in Colorado uses a 5,000-square-foot transpired collector that is expected to save about one million Btus of natural gas annually.

\section{Simple Concept}

The transpired air collector is easier to use, lower in cost, and more efficient than previous flat-plate solar air collectors made with glazing. Transpired collectors

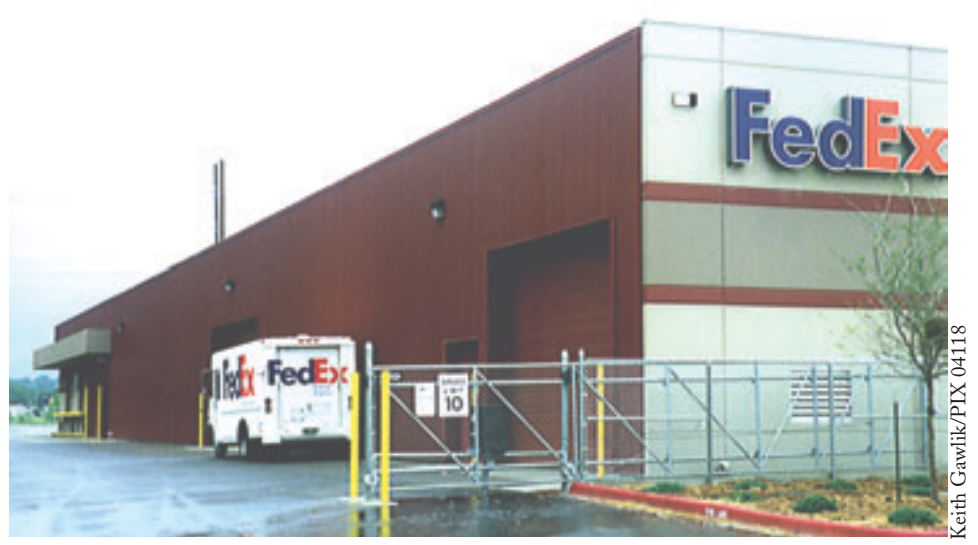

Transpired air col-

use common-wall construction with building material lector ventilation preheating technology is ideal for sunny locations with long beating seasons, such as for this Federal Express facility in Colorado. they do not use glazing, which reduces the amount sunlight absorbed by conventional flat-plate collectors, transpired air collectors are more efficient.

\section{Major Potential}

Space heating is a universal need in cold climates, as well as a major user of energy-some 13\% of U.S. energy is used for heating residential and commercial buildings alone. By reducing this energy use, transpired air collectors can also reduce building operation costs, reliance on imported fossil fuels, pollution, and greenhouse gas generation. In addition to being maintenance free, transpired collectors help eliminate temperature stratification where that is a problem.

Transpired air collector systems can be used to preheat air for standard commercial and industrial building ventilation systems. They pay for themselves quickly and produce substantial environmental and economic benefits with no negative side effects. They provide a highly effective means for substituting renewable energy for fossil fuel consumption.

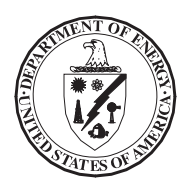

Produced for the

U.S. Department of Energy

1000 Independence Avenue, SW

Washington, DC 20585-0121

by the

National Renewable Energy Laboratory, a DOE national laboratory
Visit the Solar Buildings Program Web site: www.eren.doe.gov/solarbuildings

DOE/GO-102001-1288

Revised June 2006

Printed with renewable-source ink on paper containing at least $50 \%$ wastepaper, including $20 \%$ postconsumer waste 